\title{
Budidaya Rumput Odot dan Teknologi Pengawetan Hijauan Pakan Ternak Sapi didesa Kalibendo, Kecamatan Pasirian, Lumajang
}

\author{
Roni Yulianto $^{1 *}$, Nurwidodo ${ }^{2}$, Desy Cahya Widianingrum ${ }^{3}$, Himmatul Khasanah $^{4}$ \\ Universitas Jember, \\ Email: roniyulianto99@gmail.com ${ }^{1 *}$
}

(Diajukan: 21 November 2020, Direvisi: 22 Desember 2021, Diterima: 25 Januari 2021)

\begin{abstract}
ABSTRAK
Ketersediaan pakan yang berkualitas dan berkesinambungan merupakan salah satu faktor penentu suksesnya usaha peternakan. Untuk meningkatkat produksi hijauan pakan ternak, maka manajemen diperlukan manajemen budidaya hijauan pakan ternak, dan lahan pertanian yang digunakan. Tujuan dari kegiatan Program Pengabdian Desa Binaan (PPDB) adalah memberikan pelatihan dan pendampingan kepada petani/peternak, serta edukasi mengenai manajemen pengolahan pakan yang berkualitas dari segi nutrisi maupun jumlahnya dapat memenuhi kebutuhan hodup pokok, dan produksi ternak serta bisa digunakan untuk jangka waktu yang lama. Kegiatan PPDB dilakukan di Desa Kalibendo adalah mitra dalam program pengabdian masyarakat yang berlokasi di desa binaan Universitas Jember. Permasalahan yang ditemukan di Desa Kalibendo adalah kesulitan pakan untuk ternak selama masa kemarau serta tidak adanya tanaman hijauan pakan selain rumput yang dapat dimanfaatkan sebagai pakan ternak. Program pengabdian yang dapat dilakukan dengan memberikan penyuluhan dan pelatihan kepada petani peternak agar dapat melakukan membudidayakan hijauan pakan ternak. Eksplorasi sumber bahan pakan alternatif yang relatif murah, mudah didapat dan memiliki kandungan nutrisi yang baik seperti rumput odot. Teknologi pada pakan ternak juga dapat diterapkan sebagai contoh yaitu pembuatan silase hijauan pakan.
\end{abstract}

Kata kunci: Teknologi pakan budidaya rumput; produktifitas ternak; desa binaan,

\begin{abstract}
The availability of quality and sustainable feed is one of the determining factors for the success of a livestock business. The productivity of forage is influenced by the management of the forage cultivation and agricultural land used. The purpose of the Assisted Village Service Program (PPDB) is to provide training and assistance to farmers / breeders, as well as education on quality feed processing management in terms of nutrition and quantity that can meet basic living needs, and livestock production and can be used for a long time. PPDB activities were carried out in Kalibendo Village, Pasiria District, Lumajang Regency. Partners in this community service program are the community of livestock farmer groups in the villages of Jember University. The problems found in Kalibendo Village are the difficulty of feeding for livestock during the dry period and the absence of forage plants other than grass that can be used as animal feed. Efforts that can be done are to provide counseling to breeders to cultivate forage plants in addition to agricultural land. Exploration of alternative feed ingredients that are relatively cheap, easy to obtain and have good nutritional content, such as odot grass. Technology in animal feed can also be applied, for example, the manufacture of forage silage.
\end{abstract}

Keywords: Feed technology; grass cultivation; livestock productivity; assisted villages 


\section{PENDAHULUAN}

Desa Kalibendo terletak di kecamatan Pasirian yaitu daerah sebelah barat di Kabupaten Lumajang propinsi Jawa Timur, Indonesia. Desa ini dikenal sebagai sentra produksi gula aren. Dengan luas $689.504 \mathrm{~m}^{2}$ berbatasan dengan Desa Jugosari, Gondoruso, Jarit, dan Pasirian, dengan perkiraan luas pemukiman $1.497 .540 \mathrm{~m}^{2}$, dan luas persawahan $5.380 .000 \mathrm{~m}^{2}$ menjadikan desa Kalibendo berpotensi sebagai penghasil dari sentra pertanian. Sebagian besar penduduk desa Kalibendo bermata pencaharian sebagai petani, dimana pertanian Kalibendo merupakan daerah yang potensial untuk pengembangan usaha peernakan, dan terlihat masih banyaknya lahan yang dimanfaatkan untuk area pertanian. Selain itu di dukung juga oleh keadaan tanah Desa Kalibendo yang cukup subur. Sehingga potensi pertanian di desa Kalibendo sangat prospektif untuk kedepannya.

Berdasarkan potensi desa Kalibendo yang cukup maju di sektor pertanian, telah diidentifikasi bahwa terdapat masalah di peternakan, misalnya terbatasnya sumberdaya pakan padahal mayoritas masyarakat memiliki ternak sebanyak 2-5 ekor, sehingga permasalahan ini perlu mendapatkan apresiasi dari perangkat desa dan Universitas Jember dalam program pengabdian desa binaan menjadi potensi pengembangan desa Kalibendo sebagai desa pusat peternakan kedepanya.

Penerapan IPTEKS dengan transfer teknologi tepat guna melalui pembimbingan, pelatihan demonstrasi dan percontohan terstruktur untuk mengembangkan peternakan terpadu berbasis sumberdaya lokal di desa Kalibendo melalui program desa binaan diharapkan dapat meningkatkan kesejahteraan masyarakat melalui peningkatan ketrampilan peternak dalam budidaya, pengolahan pakan dan limbah secara efektif. Melalui program pengabdian masyarakat desa Kalibendo masih memerlukan bimbingan, pelatihan dan pendampingan mengenai budidaya ternak, pemberian pakan yang tepat, pengolahan pakan, manajemen reproduksi ternak dan pengolahan limbah ternak. Permasalahan-permasalahan yang sering muncul pada peternak masih memberikan pakan ternaknya dengan sistem tradisional dimana aspek kecukupan pakan, kebutuhan nutrisi dan kesehatan ternak tidak menjadi fokus utama. Permasalahan lain yang ditemukan di Desa Kalibendo adalah pada saat musim kemarau kesulitan hijauan pakan ternak.

Pengolahan hijauan pakan dalam bentuk silase memiliki tujuan supaya dalam pemberian hijauan pakan ternak dapat berlangsung secara merata sepanjang tahun ketersediaanya. 
Pengawetan pada pakan ternak berdampak pada keadaan fisik serta komposisi kimia hijauan dengan kehilangan sebagian dari zat makanan (gizi tanaman/nutrien) yang nantinya dapat meningkatkan nilai nutrisi dan kecernaan. Nilai nutrisi dari silase dipengaruhi faktor: jenis spesies tanaman, pertumbuhan, kandungan bahan kering saat panen, mikroorganisme yang terlibat dalam proses dan penggunaan feed additive. Sumber bahan pakan alternative dapat menjadi solusi bagi masyarakat peternak untuk menambah persediaan pakan pada musim kemarau. Budidaya rumput odot di Desa Kalibendo dapat diterapkan untuk menambah hijauan pakan.

Sehubungan permasalahan mitra, maka perlu dilakukan kegiatan pengabdian masyarakat dan pelatihan yang berorientasi pada program manajemen pakan ternak dengan tujuan: 1) mengetahui kebutuhan pakan ternak sapi;2) mengetahui manajemen pemberian dan jenis hijauan pakan ternak; 3) mengetahui cara pembuatan silase. Pengolahan hijauan pakan dalam bentuk silase juga dapat dilakukan untuk mengantisipasi terjadinya kekurangan hijauan pada musim kemarau.

\section{METODE}

Program pengabdian dan pelatihan budidaya rumput odot dan teknologi pengawetan hijauan pakan ternak sapi dilakukan didesa binaan Universitas Jember, Desa Kalibendo, Kecamatan Pasirian, Kabupaten Lumajang dilakukan pada tanggal 20-25 September 2020 yang dihadiri oleh 25 orang petani-peternak. Kegiatan pelatihan ini dilakukan selama 5 hari mulai pukul 09.30 - 13.30. Adapun beberapa metode yang dilakukan selama pelatihan antara lain sebagai berikut:

\section{Deskripsi Pelaksanaan Kegiatan dan Pendekatan}

Kegiatan program pengabdian masyarakat difokuskan pada manajemen pakan ternak yaitu dengan dasar penghitungan kebutuhan pakan sapi, pemanfaatan hijauan pakan, pengolahan hijauan pakan, serta monitoring dan evaluasi terhadap performa ternak.

1. Melakukan pelatihan cara perhitungan kebutuhan pakan ternak

2. Melakukan sosialisasi manajemen pemberian pakan ternak

3. Melakukan sosialisasi, dan budidaya rumput odot

4. Pelatihan pembuatan silase

5. Monitoring dan evaluasi kegiatan 


\section{Kelompok Sasaran}

Sasaran dalam program pengabdian kegiatan masyarakat ini adalah kelompok tani-ternak di Desa Kalibendo yang merupakan sasaran utama dalam program peningkatan sumberdaya peternak dari aspek penerapan bioteknologi budidaya rumput odot dan teknologi pengawetan hijauan pakan ternak sapi.

\section{Manajemen Pakan}

Pakan ternak adalah faktor penentu utama yang mempengaruhi keberhasilan suatu usaha peternakan. Beberapa faktor yang menyebabkan rendahnya produktivitas ruminansia di daerah tropis adalah kualitas pakan yang rendah (tingkat kecernaan dan nilai nutrisi dari pakan ternak rendah), iklim yang kurang baik (panas dan kelembaban tinggi) yang berakibat pada tingkat konsumsi yang rendah. Sumber pakan utama ternak ruminansia kecil di Indonesia secara umum adalah hijauan pakan dan limbah hasil pertanian. Hijauan pakan umumnya sering ditemukan pada lahan pekarangan rumah, tanah terlantar, lahan pertanian, pinggir jalan, maupun leguminosa. Teknologi pakan komplit merupakan campuran dari limbah agroindustri, limbah pertanian yang belum dimanfaatkan secara optimal sehingga ternak tidak perlu lagi diberi hijauan (Siregar, 2008).

Pemberian pakan dimaksudkan agar ternak dapat memenuhi kebutuhan hidupnya sekaligus untuk pertumbuhan dan reproduksi. Ransum ternak terdiri dari $60 \%$ hijauan dan 40\% limbah pengolahan pangan, sedangkan pemberian pakan konsentrat hendaknya sebelum hijauan, bertujuan untuk merangsang pertumbuhan mikrobia rumen. Pakan hijauan diberikan setelah pemerahan agar mikrobia dalam rumen dapat dimanfaatkan dan karbohidrat dapat dicerna (Lubis, 2015).

Konsumsi pakan ternak merupakan hal yang perlu diperhatikan, karena erat kaitanya dengan produksi ternak. Hal ini disebabkan oleh variasi kapasitas produksi pakan pada berbagai jenis ternak ditentukan oleh $60 \%$ dari konsumsi, 25\% dari kecernaan dan 15\% dari konversi hasil pencernaan produk (Parakkasi, 2018). Kualitas pakan yang baik, akan berdampak pada semakin tinggi konsumsi ternak. Konsumsi pakan berkualitas baik ditentukan pula oleh fisiologi ternak. Konsumsi dari bahan kering pakan ruminansia berkisar 1,5 - 3,5\% dari berat badan. Jumlah BK seekor ternak selama sehari perlu diketahui, dengan mengetahui jumlah BK yang dimakan dapat dipenuhi kebutuhan seekor hewan akan zat makanan yang 
perlu untuk pertumbuhannya, hidup pokok maupun produksinya. BK adalah tolak ukur dalam menilai palatabilitas pakan ternak yang diperlukan untuk menentukan kualitas pakan.

Teknologi pengolahan pakan dengan kadar air yang rendah (85\%) bisa memperpanjang daya simpan dan meningkatkan kualitas nutrisi pakan ternak. Teknik silase pada ransum komplit dengan memanfaatkan sumber pakan lokal (Lendrawati et al., 2012). Sumber dan ketersediaan pakan masih menjadi kendala dalam budidaya hijauan pakan ternak ruminansia. Secara umum bahan pakan bersifat musiman, terkonsentrasi di suatu wilayah. Manajemen pengelolaan pakan perlu diterapkan, dan tepat guna baik kuantitas maupun kualitasnya. Faktor penentu lainnya adalah semakin sempitnya lahan penanaman hijauan pakan yang dialih fungsikan sebagai kawasan pemukiman dan industry, sehingga mengakibatkan kualitas dan harga pakan menjadi fluktuatif, dan mempengaruhi produktivitas ternak dari segi ketersediaan bahan pakan.

Cara membuat silase (Hadju, 2014):

\section{Bahan:}

1. Hijauan $30 \mathrm{~kg}$

2. Molases $500 \mathrm{ml}$

3. EM4 $20 \mathrm{ml}$ (2 tutup botol)

4. Bekatul $3 \mathrm{~kg}$ (10\% dari $30 \mathrm{~kg}$ hijauan)

5. Air secukupnya

\section{Alat yang digunakan:}

1. Ember

2. Timbangan

3. Alas plastik

4. Drum plastik untuk silo atau kantong plastik

\section{Cara membuat:}

1. Semua bahan ditimbang

2. Menghamparkan hijauan diatas lantai yang bersih/terpal plastik

3. EM4 dan molasses dicampur, setelah itu disemprotkan pada hijauan secara merata

4. Taburkan bekatul pada hijauan secara merata

5. Tambahkan air secukupnya

6. Semua bahan di aduk merata dengan membolak balikan hijauan dan juga campuran lainya 
7. Hasil campuran dimasukkan ke dalam drum (silo) sedikit demi sedikit dan dipadatkan dengan kondisi anaerob, kemudian silo ditutup serapat mungkin agar proses fermentasi berjalan dengan baik.

8. Proses fermentasi dilakukan selama 3 minggu

9. Setelah 3 minggu hasil silase dalam silo dikeluarkan, kemudian diangin-anginkan sebelum diberikan kepada ternak untuk mengurang amonia

10. Produk pakan ternak ruminansia yang sudah difermentasi dengan kadar air dibawah $10 \%$ dapat disimpan jangka panjang untuk ketersediaan pakan ternak.

\section{Pelatihan}

Pelatihan pada kelompok ternak di wilayah Desa Kalibemdo, Kecamatan Pasiria, Kabupaten Lumajang diharapkan dapat meningkatkan pemanfaatan dalam melakukan pengolahan pakan ternak. Hal tersebut bisa dicapai dengan memberikan ilmu pengetahuan, keterampilan melalui kegiatan sosialisasi, pelatihan dan demonstrasi dilapangan.
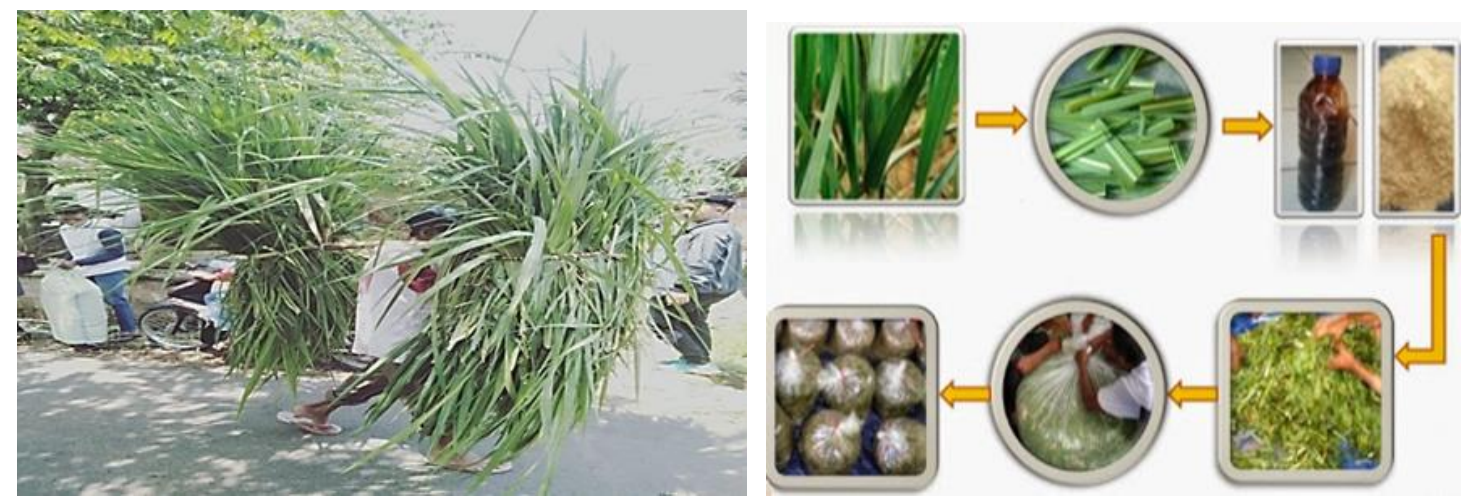

Gambar 2. Proses pengolahan pakan silase

Masyarakat Desa Kalibendo, khususnya peternak dapat memanfaatkan limbah ternak untuk meningkatkan kesuburan dan kualitas unsur hara tanah. Kotoran ternak selain dapat dijadikan sebagai pupuk kompos dapat meningkatkan kualitas unsur hara pada tanah dan juga bisa meningkatkan produksi serta kualitas nutrisi hijauan pakan ternak. Oleh karena itu, masyarakat Desa Kalibendo masih memerlukan bimbingan, pelatihan dan pendampingan mengenai budidaya ternak, pemberian pakan yang tepat, pengolahan pakan, manajemen reproduksi ternak dan pengolahan limbah ternak.

Pengawetan dan kualitas nilai nutrisi silase dipengaruhi factor: spesies tanaman, fase pertumbuhan, kandungan bahan kering saat panen, penggunaan bahan tambahan (additive), dan mikroorganisme yang digunakan (Gambar. 3) 


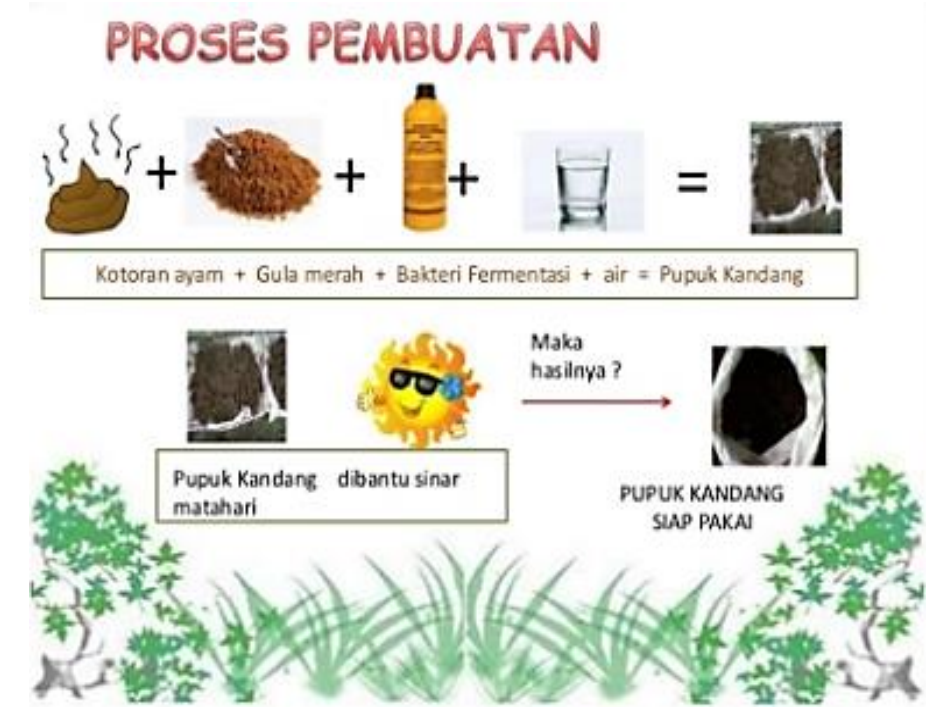

Gambar 3. Proses pembuatan pupuk organik untuk hijauan pakan ternak

\section{Solusi Pemecahan Masalah}

Pembinaan yang dilakukan terhadap desa mitra dalam program pengadian masyarakat meliputi beberapa hal yaitu: (1) Menghitungan kebutuhan pakan sapi dari segi jumlah dan kuantitas nutrisi yang dibutuhkan. Kegiatan ini memberikan pengetahuan dan wawasan tentang kebutuhan pakan sapi dari segi kualitas dan kuantitas. Manajemen pakan yang baik sangat berpengaruh terhadap produktivitas ternak. (2) pengenalan manajemen pengolahan pakan yang tepat dapat meningkatkan kecukupan ketersediaan pakan sehingga dapat mengoptimalkan produktivitas ternak serta meminimalkan anggaran biaya yang dikeluarkan peternak. (3) pengetahuan budidaya rumput odot. jenis rumput dapat dibudidayakan disuatu daerah untuk menambah stok pakan saat musim kemarau. (4) pengarahan cara pembuatan silase. Silase dapat disimpan dan digunakan peternak sebagai pakan hijauan, dan bisa dimanfaatkan dimusim kemarau. (5) monitoring dan evaluasi ternak. Aspek yang akan dilihat meliputi hasil budidaya rumput odot dan pembuatan silase pakan. Permasalahan yang sering dihadapi oleh peternak adalah mengenai manajeman budidaya ternak, kelangkaan pakan di musim kemarau, dan komposisi nutrient pakan masih sangat rendah yaitu: bahan kering = $76.60 \%$, protein kasar $=5.61 \%$, lemak kasar $=1.57 \%$, serat kasar $=25.54 \%$, total digestible nutrient $=53.07 \%$ (Yulianto $\mathrm{dkk}, 2021)$.

Program kegiatan pengabdian masyarakat ini diharapkan dapat membantu peternak lebih mandiri dan terampil dalam menerapkan budidaya rumput odot dan manajemen pengawetan pakan untuk meningkatkan produktifitas hijauan untuk dijadikan pakan ternak. 
Adapun solusi yang ditawarkan dalam pemecahan masalah pengolahan pakan dapat dilihat pada Tabel 1.

Tabel 1. Solusi yang ditawarkan untuk pemecahan masalah manajemen pengolahan pakan

\begin{tabular}{lll}
\hline No & Permasalahan & Solusi \\
\hline 1. & Belum dilakukannya perhitungan & Memberikan pengetahuan cara menghitung \\
& kebutuhan pakan ternak & $\begin{array}{l}\text { kebutuhan pakan ternak } \\
\text { 2. }\end{array}$ \\
Manajemen pemberian pakan dan & Pengolahan hijauan pakan ternak & $\begin{array}{l}\text { Memberikan pengetahuan mengenai waktu } \\
\text { pemberian pakan ternak dan jenis hijauan } \\
\text { yang dapat dimanfaatkan }\end{array}$ \\
& & $\begin{array}{l}\text { Memberikan informasi cara pembuatan } \\
\text { pakan silase }\end{array}$ \\
\hline
\end{tabular}

Kegiatan pelatihan dan pengabdian pada masyarakat berorientasi pada program manajemen pakan ternak dengan tujuan: 1) menghitung dan mengetahui kebutuhan nutrisi pakan ternak sapi; 2) mengetahui manajemen pemberian dan jenis hijauan pakan ternak; 3) mengetahui cara pembuatan silase. manajemen pengolahan pakan ternak yang perlu diperhatikan, antara lain dapat dilihat pada Tabel. 2.

Tabel 2. Manajemen pengolahan pakan

\begin{tabular}{|c|c|c|}
\hline No & Tujuan Segi & Nilai Tambah \\
\hline 1 & Manajemen & $\begin{array}{l}\text { - Manajemen tepat guna } \\
\text { - Mudah dipahami } \\
\text { - Murah dan sederhana }\end{array}$ \\
\hline 2 & Operasional & $\begin{array}{l}\text { - Mudah dioperasikan tanpa training } \\
\text { - Tidak rumit penerapannya } \\
\text { - Hemat dan murah }\end{array}$ \\
\hline 3 & $\begin{array}{l}\text { Pengaruh manajemen } \\
\text { pengolahan pakan }\end{array}$ & $\begin{array}{l}\text { Manajemen pengolahan pakan yang tepat dapat } \\
\text { memberikan } \\
\text { hasil yang baik }\end{array}$ \\
\hline 4 & Dampak sosial & Meningkatkan kesejahteraan ekonomi peternak \\
\hline
\end{tabular}

\section{Rancangan Evaluasi}

Hilirisasi bioteknologi yang digunakan dapat mengatasi kelangkaan pakan dimusim kemarau, meningkatkan kualitas nutrient pakan, memperpanjang masa simpan pakan dengan memanfaatkan limbah jerami padi/pengawetan hijauan pakan ternak seperti silase dan pakan fermentasi (Yulianto et al., 2020). Evaluasi keberhasilan manajemen pengolahan pakan dilakukan setelah proses sosialisasi, pelatihan dan demonstrasi. Adapun rancangan evaluasi manajemen pengolahan pakan dapat dilihat pada Tabel 3. 
Tabel 3. Rancangan Evaluasi Manajemen Pengolahan Pakan Ternak

\begin{tabular}{|c|c|c|c|}
\hline No & Kriteria & Indikator & Tolak Ukur \\
\hline 1 & $\begin{array}{l}\text { Kapasitas } \\
\text { sumber daya } \\
\text { manusia }\end{array}$ & $\begin{array}{l}\text { Perubahan } \\
\text { perilaku sosial }\end{array}$ & $\begin{array}{l}\text { a. Mampu menerapkan budidaya rumput odot } \\
\text { sebagai pakan ternak sapi } \\
\text { b. Mampu menerima pengetahuan } \\
\text { c. Memiliki wawasan luas kedepan }\end{array}$ \\
\hline 2 & $\begin{array}{l}\text { Manajemen } \\
\text { pakan }\end{array}$ & $\begin{array}{l}\text { Hasi } \\
\text { rum }\end{array}$ & $\begin{array}{l}\text { a. Keberhasilan membuat pakan silase } \\
\text { b. Adanya pakan ternak pada musim kemarau }\end{array}$ \\
\hline 3 & Sosial ekonomi & $\begin{array}{l}\text { Kondisi } \\
\text { masyarakat }\end{array}$ & $\begin{array}{l}\text { Meningkatkan kesejahteraan yaitu adanya } \\
\text { peningkatan pendapatan }\end{array}$ \\
\hline
\end{tabular}

\section{HASIL, PEMBAHASAN, DAN DAMPAK}

Program pengabdian dan pelatihan budidaya rumput odot dan teknologi pengawetan hijauan pakan ternak sapi dilakukan pada tanggal 20-25 September 2020 yang dihadiri oleh 25 orang petani-peternak. Kegiatan pelatihan ini dilakukan selama 5 hari mulai pukul 09. 30 13.30. Kegiatan program pengabdian dan pelatihan ini diisi oleh pemateri dari Dosen Program Studi Peternakan, Fakultas Pertanian, Universitas Jember. Adapun langkah-langkah yang akan dilakukan dalam program pengabdian masyarakat antara lain sebagai berikut:

1. Sosialisasi dan memberikan pelatihan mengenai pentingnya pemanfaatan budidaya rumput odot dan teknologi pengawetan hijauan pakan ternak sapi.

2. Teknologi pengawetan dan budidaya rumput odot dalam meningkatkan kualitas nutrisi hijauan pakan ternak, produktifitas ternak, dan ketersediaan/penyimpanan bisa digunakan dalam jangka waktu yang lama.

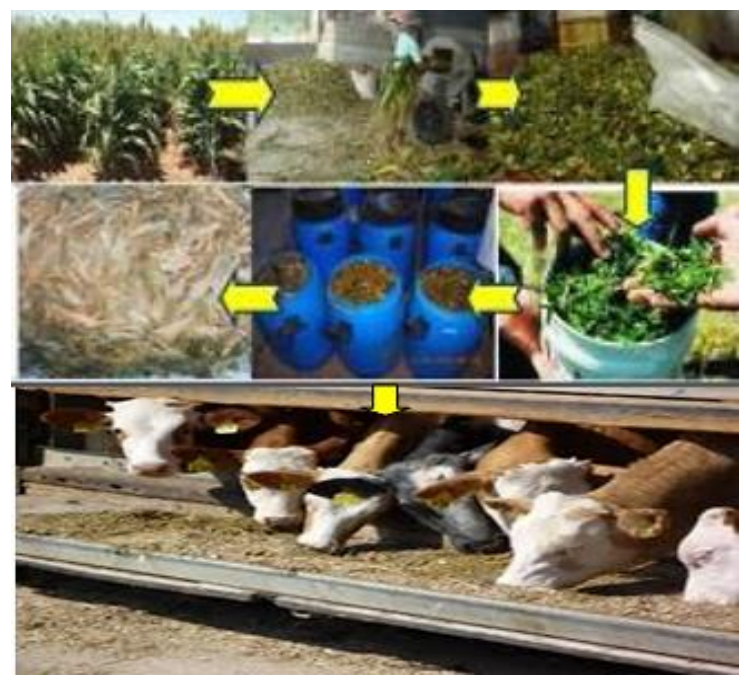

Gambar 4. Proses pembuatan pakan silase untuk ternak ruminania 
Konsumsi/kecernaan dipengaruhi faktor kualitas pakan dan oleh kebutuhan energi ternak. Pakan yang dikonsumsi oleh merupakan faktor penting yang secara langsung mempengaruhi produktivitas ternak. Kualitas pakan yang semakin baik semakin tinggi konsumsi pakan seekor ternak. Konsumsi pakan berkualitas baik ditentukan pula oleh status fisiologi seekor ternak. Bahan Kering (BK) merupakan tolak ukur untuk menilai palatabilitas dan mutu suatu pakan. serta diperlukan untuk menentukan mutu/kualitas pakan ternak (Yulianto et al., 2017).

Kemampuan mengkonsumsi pakan perlu diperhatikan karena erat kaitanya dengan tingkat produksi ternak. Variasi produksi pakan ternak dengan berbagai jenis varietas ditentukan oleh konsumsi (60\%), konversi hasil pencernaan produk (15\%), dan kecernaan (25\%) (Parakkasi, 2018). Konsumsi BK pakan ternak ruminansia berkisar 1,5 - 3,5\% dari berat badannya.

\section{SIMPULAN}

Dari hasil kegiatan Program Pengabdian Desa Binaan (PPDB) dengan topik "Budidaya Rumput Odot dan Teknologi Pengawetan Hijauan Pakan Ternak Sapi didesa Kalibendo, Kecamatan Pasirian, Lumajang” sangat dibutuhkan peranan perangkat desa guna memotivasi petani/peternak dalam meningkatkan sumberdaya manusia peternak untuk lebih maju dan berkembang, terutaman dalam memanfaatkan potensi lahan yg tidak produktif menjadi lahan produktif untuk ketersediaan hijauan pakan ternak baik dari segi kualitas nutrisi maupun quantitas dari segi jumlahnya, sehingga dapat memenuhi kebutuhan pakan ternak Dari hasil program kegiatan pengabdian masyarakat perlu dilakukan evaluasi dalam pembinaan peternak untuk lebih produktif.

\section{UCAPAN TERIMAKASIH}

Tim Program Pengabdian Desa Binaan (PPDB) mengucapkan terima kasih kepada a) LP2M (Lembaga Penelitian dan Pengabdian kepada Masyarakat) Universitas Jember; b) KeRis (Kelompok Riset) Animal Breeding and Production); c) PS Peternakan Fakultas Pertanian Universitas Jember; e) Perangkat Desa Kalibendo, Kecamatan Pasirian, Kabupaten Lumajang Provinsi Jawa Timur. 


\section{DAFTAR PUSTAKA}

Hadju. 2014. Pengaruh pakan limbah organik terhadap produksi, kualitas dan keamanan susu serta produksi biogas sapi perah. Jakarta: Badan Penelitian dan Pengembangan Pertanian.

Lendrawati, nahrowi, dan M. Ridla. 2012. Kualitas Fermentasi Silase Ransum Komplit Berbasis Hasil Samping Jagung, Sawit dan Ubi Kayu. Fakultas Peternakan, Universitas Andalas.

Lubis, A.U. 2015. Kelapa Sawit (Elaeis guineensis Jacq.) di Indonesia. Pusat Perkebunan Marihat. Bandar Kuala. Pematang Siantar. 435 Hal.

Parakkasi, A.2018. Ilmu Nutrisi dan Makanan Ternak Ruminansia.Universitas Indonesia Press. Jakarta.

Siregar. 2012. Ransum Ternak Ruminansia. Jakarta: Penebar Swadaya.

Yulianto, R., Nurwidodo, N., Widianingrum, D., \& Khasanah, H. (2021). Bioteknologi Fermentasi Jerami Padi Tinggi Nutrisi, Guna Meningkatkan Kemandirian dan Kesejahteraan Peternak di Desa Kalibendo. JPKMI (Jurnal Pengabdian Kepada Masyarakat Indonesia), 2(1), 23-32. doi: 10.36596/jpkmi.v2i1.126

Yulianto, R., Setyawan H.B., Arum, A.P. (2)020. The effect of environmental factor in spring and summer season to select dominance of plant species as cattle feed in Japan. Full Paper Proceeding Journal ISWPI.

Yulianto, R., Xuan, T, D., Khanh, T.D., Minh, T.N., Anh T.T.T, Huong, C.T. (2017). Evaluation of Dominant Plant Species for Animal Feeds in Grazing Areas. Project: Exploitation of candidate genes of interest from native Vietnamnese rice landraces. Diambil dari: https://www.researchgate.net/publication/319143887_Evaluation_of_Dominant_Plant_S pecies_for_Animal_Feeds_in_Grazing_Areas

Yulianto, R., Xuan, T.D, Khanh, T.D., Minh, T.N., Anh, T.T.T., Huong, C.T. 2017. Evaluation of Dominant Plant Species for Animal Feeds in Grazing Areas. International Journal of Agriculture, Forestry and Fisheries. Vol 5(3): 29-33. 